\title{
Agility and Leg Power Comparison between University Indoor and Beach Volleyball Players 大學排球與沙灘排球選手靈敏度及㯈肌力的比較
}

\author{
Kim Geok SOH \\ Department of Sport Studies/ \\ Sports Academy, \\ Faculty of Educational Studies, \\ University Putra Malaysia, \\ MALAYSIA
}

\author{
Aminuddin bin Yusof \\ Department of Sport Studies, \\ Faculty of Educational Studies \\ University Putra Malaysia, \\ MALAYSIA
}

\author{
Kim Lam SOH \\ Department of Medicine, \\ Faculty of Medicine \& \\ Health Sciences, \\ Universiti Putra Malaysia, \\ MALAYSIA
}

\author{
Mohd. Sofian Omar Fauzee \\ Center of Education Studies and \\ Modern Languages, \\ Northern University of Malaysia, MALAYSIA
}

\author{
Hiong Kwong $\mathrm{MOH}$ \\ Department of Sport Studies, \\ Faculty of Educational Studies, \\ University Putra Malaysia, MALAYSIA
}

\section{蘇金玉 \\ 馬來西亞博特拉大學教育研究系 \\ 教育研究院運動體育學系}

\section{阿米努丁尤索夫}

馬來西亞博特拉大學

體育學系

\section{莫哈末蘇菲安 \\ 馬來西亞北方大學 \\ 教育研究與現代語言}

蘇金蘭

馬來西亞博特拉大學醫學系

醫學及健康科學學系

\author{
毛害廣 \\ 馬來西亞博特拉大學 \\ 教育研究系教育研究院運動部
}

\begin{abstract}
This study sought to compare the agility and leg power between indoor and beach volleyball players in Malaysia, and to investigate the differences for the above variables within gender. The subjects were 25 Malaysian players (6 for beach volleyball and 19 for indoor volleyball) who represented Malaysia in the ASEAN University Games in August 2008 in Kuala Lumpur. The SEMO agility test and Vertical Jump test were used to measure agility and leg power, respectively. The data were analysed descriptively, and the T-test used to establish significant differences between the players. Overall, there was a significant difference in agility between the indoor and beach players $(\mathrm{f}=7.60, \mathrm{p}<0.01)$, where the beach volleyball players were reported to be more agile. In addition, a significant difference was also reported for leg power between male indoor and beach volleyball players ( $\mathrm{f}=1.47, \mathrm{p}>0.24)$ - the beach players being stronger in term of leg power. There was a similar superiority in agility by the female beach players. The only superiority of the indoor over beach players was by the males in agility.
\end{abstract}

Key Words: Agility, leg power, volleyball players, gender, university player 


\section{摘 要}

本研究旨在比較大學排球隊員, 與沙灘排球員的身體靈敏度, 以及腿部肌肉力量。邀請了25位代表馬來西亞出席世界大學生 運動會的球員參與本研究, 結果顯示 : 沙排球員的靈敏度整體較佳, 男沙排球員的腿部爆發力則較強。

關鍵詞：腿爆發力、大學排球員

\section{Introduction}

Conventional volleyball was introduced about 100 years ago, played by six players a team, usually indoors (FIVB, 2010; Miller, 2005). Beach volleyball came later, but both were together included in the Olympic Games in 1996 in Atlanta, USA (Olympic Organistion, 2010). Both volleyball games require similar playing techniques, with only differences in the environment and playing styles. According to Smith (2006), movements in indoor and beach volleyball are different because of the different ways of funning on sand and a hard floor. In addition, the beach game has only two players, requiring more running. A good volleyball player requires good acceleration/deceleration, and good swerving ability (Bissell, \& Duke, 2007; Gabbett et al., 2006). Furthermore, court sports, as volleyball is, often require zig-zagging with 1800 turns over small distances (Barnes et al., 2007). Hence, this study was conducted to compare the agility and leg power between indoor and beach volleyball players in Malaysia, and to investigate the differences on the variables within gender based on games type.

\section{Methods and Procedures \\ Subjects}

Twenty-five Malaysian volleyball players who represented Malaysia in the ASEAN University Games (August 2008) in Kuala Lumpur were selected as subjects - 19 indoor (11 males, 9 females) and 6 beach (2 males, 4 females) volleyball players, all 18 to 26 years old. The fewer beach volleyball players was because of their limited pool, restricted by the requirement that they must have represented Malaysia in the August 2008 games.

A beach volleyball team has only two players, with no reserve(s) allowed, while team / indoor volleyball is played by teams of six players with $1-6$ reserves allowed. For the August 2008 games, Malaysia sent a team of men and two of women for beach volleyball, and a team each of men and women for indoor volleyball. The total number of indoor volleyball players was 19 - 11 males and 8 females. On the other hand, beach volleyball had total players of only 2 males and 4 females - thus, the dearth of beach players for this study. The physical attributes of the players are shown in Table 1.

Table 1. Physical Attributes of Volleyball Players.

\begin{tabular}{lcccccc}
\hline Physical & \multicolumn{2}{c}{ Indoor $(\mathrm{N}=19)$} & \multicolumn{2}{c}{ Beach $(\mathrm{N}=6)$} & \multicolumn{2}{c}{ AVERAGE (N=25) } \\
\cline { 2 - 7 } Characteristic & Male & Female & Male & Female & MALE & FEMALE \\
& $(\mathrm{n}=11)$ & $(\mathrm{n}=8)$ & $(\mathrm{n}=2)$ & $(\mathrm{n}=4)$ & $(\mathrm{N}=13)$ & $(\mathrm{N}=12)$ \\
\hline Age (Years) & $21.09 \pm 1.64$ & $20.13 \pm 1.81$ & $21.00 \pm 0.00$ & $24.00 \pm 1.41$ & $21.08 \pm 1.50$ & $21.42 \pm 2.50$ \\
Height $(\mathrm{cm})$ & $182.63 \pm 6.22$ & $169.69 \pm 3.81$ & $185.00 \pm 6.36$ & $174.88 \pm 2.78$ & $182.99 \pm 6.03$ & $171.42 \pm 4.23$ \\
Body Mass $(\mathrm{kg})$ & $69.40 \pm 10.15$ & $61.78 \pm 3.92$ & $76.85 \pm 3.32$ & $62.25 \pm 3.40$ & $70.55 \pm 9.73$ & $61.93 \pm 3.60$ \\
\hline
\end{tabular}

\section{Procedure and Instrumentation}

Agility was determined using the SEMO Agility Run test (Johnson, \& Nelson, 1986), and leg power by the Vertical Jump test (Johnson, \& Nelson, 1986). Both tests were chosen because of the similarities shown with the movement played in volleyball games and because they were reported to have high validity and reliability $(r>0.87)$.
Besides, both tests were also used by other researchers to measure agility and leg power (Bishop, 2003; Van Lieshout, \& Lombard, 2004; Ziv, \& Lidor, 2010). For each test, the subject was tested twice and the best time/ distance measured taken. 


\section{Statistical Analysis}

Descriptive statistics, such as minimum value, maximum value, mean and standard deviation values, were used to describe the agility and leg power of the players, and the T-test used to compare the differences between them.

\section{Results}

Overall, the beach players performed better in both tests although significance was only reported for the SEMO Agility Run test ( $\mathrm{f}=7.60, \mathrm{p}<0.01$ ). The mean time by the beach players for the test was 11.66 seconds vs. 11.78 seconds by the indoor players. A nonsignificant difference was reported for leg power ( $\mathrm{f}=1.47$, $\mathrm{p}<0.24)$ with the beach players jumping higher at 69.50 vs. $68.95 \mathrm{~cm}$.

Table 2. Agility and Leg Power for Volleyball Players.

\begin{tabular}{lcccccc}
\hline Test & Volleyball Team & $\mathrm{N}$ & Mean & SD & $\mathrm{F}$ & Sig. (p) \\
\hline SEMO & Beach & 6 & $11.66 \mathrm{~s}$ & 0.21 & 7.60 & 0.01 \\
& Indoor & 19 & $11.78 \mathrm{~s}$ & 0.69 & & \\
\cline { 2 - 7 } Vertical Jump & Beach & 6 & $69.50 \mathrm{~cm}$ & 14.24 & 1.47 & 0.24 \\
& Indoor & 19 & $68.95 \mathrm{~cm}$ & 17.33 & & \\
\hline
\end{tabular}

Among the females, the beach players were better in both tests (Table 3), scoring 11.69 seconds for agility and $61.00 \mathrm{~cm}$ for jumping. However, the differences were not significant for the females. The male beach players were also reported to be more superior in leg power (Table 4), jumping $86.50 \mathrm{~cm}$ against 82.27 , significantly better at $\mathrm{f}$
$=4.88, \mathrm{p}<0.05$. On the other hand, the indoor male players were more agile, taking 11.36 seconds on average to complete the SEMO circuit vs. 11.69 seconds by their 'opponents'. The difference was, however, not significant.

Table 3. Agility and Leg Power of Women Volleyball Players.

\begin{tabular}{lcccccc}
\hline Test & Volleyball Team & $\mathrm{N}$ & Mean & SD & F & Sig. (p) \\
\hline SEMO & Beach & 4 & 11.69 & 0.22 & 0.70 & 0.42 \\
& Indoor & 8 & 12.36 & 0.42 & & \\
Vertical Jump & Beach & 4 & 61.00 & 6.68 & 2.09 & 0.18 \\
& indoor & 8 & 50.63 & 2.93 & & \\
\hline
\end{tabular}

Table 4. Agility and Leg Power for Male Volleyball Players.

\begin{tabular}{lcccccc}
\hline Test & Volleyball Team & $\mathrm{N}$ & Mean & SD & F & Sig. (p) \\
\hline SEMO (second) & Beach & 2 & 11.60 & 0.26 & 0.94 & 0.35 \\
& Indoor & 11 & 11.36 & 0.51 & & \\
Vertical Jump (cm) & Beach & 2 & 86.50 & 3.54 & 4.88 & 0.05 \\
& Indoor & 11 & 82.27 & 8.41 & & \\
\hline
\end{tabular}




\section{Discussion}

\section{Overall Results}

The beach players were significantly more agile than the indoor players, possibly due their training on sand. According to Smith (2006), the mechanics of indoor and beach volleyball are more or less the same, but it is much more difficult to run and maneuver on 'sticky' sand (for beach volleyball) than a hard floor (for indoor volleyball). Training on sand should thus have afforded the beach players greater agility (Karch and Byron, 1999). Besides, beach volleyball is played by two players with no substitutes allowed (vs. six for indoor volleyball with six substitutes). Although, the layout for the beach volleyball court is smaller - $8 \mathrm{~m}$ wide X 16 meter long as compared to the indoor volleyball court which is 9 meter wide X 18 meter long (FIVB, 2010), the area need to be cover per player is relatively larger for the beach volleyball. This is in line with Smith (2006) who found that the number of players in the ring had an influence on the pattern of movement in the courts.

The Vertical Jump test found no significant difference between the indoor and beach players. Thus, the training in different environments did not have much impact on jumping ability. This is in line with Bishop (2003) who found jumping to be a general ability in volleyball players, not greatly affected by the surface of training. However, Barnes et al. (2007) found that volleyball players who trained predominantly in the vertical domain may also have improved agility countermovement performance.

\section{Based on Gender}

There was no significant difference in agility between male indoor and beach players. Based on the SEMO test norms by Johnson and Nelson (1986), the beach players were at intermediate agility and the indoor players at advanced intermediate. The limited number of beach volleyball players was acknowledged to be one of the reasons. Besides, in Malaysia, all the beach players first started with the indoor game before turning to their present game which is a very new sport with few adherents (Bishop, 2003). Some players remain involved in both games, and so train under both conditions. The duration of training for both conditions in a particular court may influence the results of this study. There was a significant difference in leg power between the male indoor and beach players. Based on the vertical jump norms by Anonymous (2009), both sets of players had excellent leg power, with the indoor players much better. However, the result has to be taken with caution because there were so few beach subjects to compare with. Overall, all the players had adequate jumping ability to play volleyball at the national level.

Agility and leg power in the female beach players were better than in the female indoor players. Comparing with the norms by Johnson and Nelson (1986) and Anonymous (2009), the female beach players were excellent for both tests, while the female indoor players only advanced intermediate for agility and very good for leg power. However, the differences in agility and leg power were not significant. Similar finding was also reported in the study by Barnes et al. (2007) and Hennessy et al. (2001) who found that agility and jumping performance were closely correlated. As the results, players who reported to have good agility performance were usually also reported to have good jumping ability and vice verse (Smith, Roberts, \& Watson, 1992).

\section{Conclusions}

From this study, several conclusions can be drawn. Overall, the beach players had better agility and leg power than the indoor players. The superiority was also shown by the female beach players over their indoor counterparts. Although the male beach players could jump better than the male indoor players, they were less agile. Unequal subjects comparison between indoor and beach volleyball players was noted as one of this study's limitations, while the different environments of play and rules of the games might be the other reasons causing the differences between the different volleyball players.

\section{Acknowledgements}

The authors would like to thank all the people involved in this research. Special thanks and our gratitude are also expressed to the Malaysian Volleyball Association, volleyball coaches, and subjects of this research. 


\section{References}

Anonymous. (2009). Vertical Jump Test Measure Your Vertical Jump. Retrieved 20 Sept., 2010, from http:// www.verticaljumpmanual.com/vertical-jump-test-measureyour-vertical-jump

Barnes, J. L., Schilling, B. K., Falvo, M. J., Weiss, L. W., Creasy, A. K., \& Fry, A. C. (2007). Relationship of jumping and agility performance in female volleyball athletes. The Journal of Strength \& Conditioning Research, 21(4), 1192.

Bishop, D. (2003). A comparison between land and sandbased tests for beach volleyball assessment. Journal of Sports Medicine and Physical Fitness, 43(4), 418423.

Bissell, K., \& Duke, A. (2007). Bump, Set, Spike: An Analysis of Commentary and Camera Angles of Women's Beach Volleyball During the 2004 Summer Olympics. Journal of Promotion Management, 13(1), 35-53.

FIVB. (2010). FIVB Refereeing Guidelines and Instructions 2010. Retrieved 20 Sept, 2010, from http://www.fivb. ch/EN/Volleyball/Rules/FIVB_Refereeing_Guidelines_ and_instructions_2010.pdf

Gabbett, T., Georgieff, B., Anderson, S., Cotton, B., Savovic, D., \& Nicholson, L. (2006). Changes in skill and physical fitness following training in talentidentified volleyball players. The Journal of Strength \& Conditioning Research, 20(1), 29.

Hennessy, L., \& Kilty, J. (2001). Relationship of the stretch-shortening cycle to sprint performance in trained female athletes. Journal Strength and Conditioning Research, 15, 326-331.

Johson, B. L., \& Nelson, J. K. (1986). Practical Measurements for Evaluation in Physical Education (4th ed.). Champaign, IL: Human Kinetics.
Miller, B. (2005). The volleyball handbook. Champaign, IL: Human Kinetics Publishers. Olympic Organistion. (2010). International Volleyball Federation, . Retrieved 20 Sept, 2010, from http://www.olympic.org/en/content/ Sports/All-Sports/VolleyBall/Volleyball/InternationalVolleyball-Federation/

Smith, D. J., Roberts, D., \& Watson, B. (1992). Physical, physiological and performance differences between Canadian national team and universiade volleyball players. Journal of Sports Sciences, 10(2), 131-138.

Smith, R. (2006). Movement in the Sand: Training Implications for Beach Volleyball. Strength \& Conditioning Journal, 28(5), 19.

Van Lieshout, K. A., \& Lombard, A. J. J. (2004). Fitness profile of elite junior South African badminton players. African Journal for Physical, Health Education, Recreation and Dance, 9(3), 114-120.

Ziv, G., \& Lidor, R. (2010). Vertical jump in female and male volleyball players: a review of observational and experimental studies. Scandinavian Journal of Medicine \& Science in Sports.

\section{Correspondence:}

Soh Kim Geok PhD

Associate Professor

Department of Sports Studies

Faculty of Educational Studies

University Putra Malaysia

43400, Serdang, Selangor, Malaysia

P: +60 389468153

F: +60 389468552

M: +60 (19) 3649715

Email: kimgeoks@yahoo.com;

kims@putra.upm.edu.my 